\title{
THE BIOENERGY VILLAGE MOVEMENT IN GERMANY - AGRARIAN BACKWARDNESS OR FUTURE ORIENTED RE-ORGANISATION OF THE ENERGY SYSTEM?
}

\author{
Gerhard Fuchs
}

Department of Social Sciences

University of Stuttgart

Seidenstr. 36/II, D-70174 Stuttgart, Germany

e-mail: gerhard.fuchs@sowi.uni-stuttgart.de

\begin{abstract}
Germany is in the process of transforming its system of electricity generation and distribution. The transformation process was advanced by a number of civil society actors keen on dismantling the old centralised, undemocratic, environmentally unsound and unhealthy system, and replacing it with a new one, closer to the people, decentralised and using renewable energies. One type of transformative activity is linked to the bioenergy village movement, which can be found in mainly agricultural areas and which largely relies on biomass as a transition technology. To date a systematic analysis of these attempts is lacking. This paper will place relevant activities in the context of the German electricity transition and analyse the actors involved in this movement, their driving motivations and strategies. It will show that despite their small scale character, the movement constitutes an important building block of a new electricity infrastructure. Further discussion will be made whether the theoretical framework chosen (theory of strategic action fields) to study the movement is well suited to analyse similar processes of transformation.

The research performed was part of the German Helmholtz alliance "Energy-trans: Future infrastructures for meeting energy demands. Towards sustainability and social compatibility".
\end{abstract}

Key words: biomass, electricity transition, Germany, bioenergy villages, social entrepreneurs

\section{INTRODUCTION}

The process of institutional transformation that has allowed experiments aimed at developing new ways of generating and distributing electricity to become an established part of a new electricity system can be observed on the example of Germany. Within the last two decades, the expectations of how the German system of electricity generation and distribution should work has changed dramatically. In the early to mid-nineties, there was a consensus among the incumbent government and industry representatives that there was no real alternative to the then existing electricity system relying on a centralised architecture with large power plants, owned by major utility companies and running on fossil fuel or nuclear energy. Twenty years later, the government and main opposition parties, along with old and new industry actors, reached a consensus that nuclear energy 
is to be taken out of the system by 2022, and that many of the old fossil fuel sourced power plants need to be de-commissioned with renewable energies becoming the new cornerstone of the system (Bundesregierung, 2016). In this context, renewable energies are being harvested and run by a host of new actors, which to date have not played a significant role in the German energy system. How did this transformation come about? Was it the product of conscious experimentation by some actors? What was and is the role of the state and non-state agents, policy entrepreneurs, intermediaries and various discursive and material elements in building momentum for the expansion of experiments beyond the niche in which they were initially embedded?

In order to answer these questions, this section will first clarify the understanding of "experiments" and "niches". Secondly, a brief overview of the history of the German electricity transition will be presented. An overview of the historical process is necessary to understand the extent to which it is feasible to talk about "experiments" and their embedding in the unfolding of the transition. Based on this, the German bioenergy village movement will be analysed as an example of a post-experimental setting in the German transformation. The bioenergy village movement represents one type of actor (among many) which tried and tries to work on a decarbonised and decentralised energy supply. The movement will be positioned in the overall transformation process and its effects on the transformation will be assessed. The paper will conclude with an assessment of the role of challenger actors in the process of transformation and the embedding of experiments. The section uses the theory of strategic action fields as a heuristic guideline for presenting the results. It is a relational general sociological theory rooted in symbolic interactionism and organisational neo-institutionalism which emphasises the role of real actors in the processes of collective actions aimed at sustaining or changing social order (Fligstein and McAdam, 2012; Padgett and Powell, 2012).

\section{TRANSITIONS AND THE THEORY OF STRATEGIC ACTION FIELDS}

Empirically, the case has been made that the German energy transition is a process being advanced by challenger or local actors using small-scale technology (e.g. Geels et al., 2016). Theoretically, the search for an answer to the question how "new" organisations, markets etc. emerge has directed attention to the activities of real actors and the networks they are embedded in (Padgett and Powell, 2012). This section will try to combine the two above insights when looking at "bioenergy villages". The bioenergy village movement as a category used by the federal government appeared at a time when small-scale experiments had turned into an officially legitimised activity. Policy experiments actually have a long history in Germany. The first wave of experiments was conducted in the 1980s, when the government introduced liberalisation and deregulation policies in a number of fields. In order to counter the dominant public mood against these policies, they were labelled as experiments and pilot projects to conjure up an image of reversibility. Little has been actually reversed, but they were used for fine tuning specific measures. Since then they have 
become an established piece in the repertoire of policy instruments. The electricity experiments in the late 1980s and 1990s were different because they were not the direct result of government policy. These experiments were bottom up events and directed against the official federal policy. Only later did they gain official recognition and support.

In this section it will be argued that a sociology in the tradition of Max Weber is first of all interested in understanding and explaining social action (Martin, 2011). As Padgett and Powell (2012) state: "In the short run, actors create relations; in the long run, relations create actors." (Padgett and Powell, 2012:25). The cornerstone of such an approach therefore is to look at social interactions. Institutions and technologies become of importance when they affect social actions. They do not possess an independent existence beyond these interactions, even if they are perceived by actors as being very stable, objective and demanding. Social actions are of course influenced by the specific "local context" in which they take place and can only be understood with reference to the specific context in which they are performed. The local context can be conceptualised as a field. Field theory based approaches (Martin, 2003; Fligstein and McAdam, 2011; 2012) claim that all fields as orders within which social action takes place relate to an identifiable problem and in dealing with the problem develop a specific social structure. An important element of this social structure is that actors can be distinguished, with command over different amounts of resources, in the pursuit of a variety of strategies and occupying different positions within the field. Sometimes a distinction is made between members and non-members in a field, and Bourdieu (1992) distinguishes between dominating and dominated actors, while the most prevailing distinction is the one between incumbent and challenger actors. As such, incumbent actors possess a dominant role within a field, command more resources and are better able to steer the developments in a direction that supports their status. Therefore it is obvious that incumbent actors will usually not have much interest in undermining their own position, or in changing the rules of the game so as to put their very own position at risk.

In order to identify the incumbents and the challengers, it is first necessary to identify the field being discussed. Talking meaningfully about rules, institutions, and expectations implies that they are common to a specific, identifiable group of actors. The field of electricity generation is dominated by the actors responsible for the task of "producing electricity" and there are rules that regulate who under what conditions is allowed to do what, as there are also implicit rules concerning what the actors consider to be legitimate actions. The role of mayors or city councils in developing plans for sustainability and energy transitions have been analysed in many case studies (Priemus and Davoudi, 2014; Mieg and Toepfer, 2013). Observers consider them to be the incumbents, because at a specific moment they possess a politically powerful position. However, in most cases state actors or political actors are not competing in the field under investigation properly, e.g. electricity supply. They are on the outside trying to regulate the field. The field of electricity supply is populated firstly by the actors responsible for providing energy. Political decision makers then and there concern themselves with energy questions, but are not routinely involved in the business. If the system of energy provision changes due 
to new political decisions, this is the result of bargaining mainly between politicians and, very often, changing majorities. In the communities that we have analysed, everything can be observed from a conflict over energy questions, which led to a new majority in a city council up to the attempt to use the energy question to keep one's position as a well respected mayor. If the mayor or city council wishes to change the energy system, they have to engage with the incumbent actors in the field who will usually try to resist decisions that might result in a change of their status. This differentiation is useful to make because it sheds light on the different games actors play (Scharpf, 1997) and the different logic that drives the activities of actors. Mobilising a community, generating electricity at market prices, or building a political majority in parliament are different things that can influence each other but which follow different logic and mostly involve different actors. "The city" or "the mayor" are abstract categories with little analytical purchase. Whether a mayor supposedly acts as a regime actor or against the regime has nothing to do with the official position they hold.

Based on these theoretical considerations, we conceive experiments as attempts by actors to work with alternatives to a dominant field logic. These experiments are conducted by challenger actors, who aim at re-organising a field by developing new cognitive frames on how to address a specific problem (e.g. supply of electricity), organise, build coalitions and implement novel organisational solutions. In this way, experiments are not conceived as allowing for hypothesis-testing through repeatable observations and the introduction of variations in a controlled setting (the laboratory). Rather we are dealing with experimentation as a transformational practice. This has to be seen in contrast to learning processes in which the incumbents are engaged. The behaviour of the incumbents is not static, as they are constantly trying to adapt to new challenges coming from the environment and continuously devising new schemes that will help them to preserve their status in an ever-changing world. We will not be covering all of these activities. Our interest is in the development of new organisations and markets that are destabilising the existing social structure and which are implicitly or explicitly aiming at a transformation of the dominant order.

Our perspective is special insofar as we do not treat the experiments as something given. We distinguish between the stage in which an experiment is planned and created and the stage when an experiment is being conducted and needs to be stabilised, especially when it is oriented towards diffusion. It is important to make this distinction because different mechanisms appear when dealing with the situation of genesis as compared to the situation of stasis. Dealing with experiments in this way furthermore gives us a specific place in the experiment discussion literature. Firstly we leave aside the assumption often taken over from science that social experiments can be treated in a similar manner as laboratory experiments with the aim of developing an optimal or near optimal solution. Secondly, we gather that there is no inherent necessity for diffusing an experiment. If a solution is found to be working in a specific local context, it need not necessarily work in other local contexts as well and / or the people engaged in developing this solution will see it as their task to diffuse it. This should not imply, however, that there might not be cases of expe- 
rimenting that are explicitly oriented toward finding a generic solution, a solution which will work in a variety of local contexts. We just remain open minded and will consider what the actors intend to do without judging their behaviour right from the start.

\section{ELECTRICITY TRANSITIONS IN GERMANY}

From the beginning debates about electricity transitions in Germany have stressed two aspects: the use of renewable energy (RE) as a substitute for nuclear energy and fossil fuels, and the decentralised architecture of a new system of electricity generation and supply (Fettke and Fuchs, 2016). The second aspect especially continues to be of a highly contentious character. Renewable energy can be harvested and run in a more centralised manner by using large solar farms and vast (offshore) wind parks - administered, for example, by established big energy providers or major investors. On the other hand, many actors on the local level are driven by the idea that electricity generation should be dramatically decentralised both from a technological as well as an organisational aspect and some form of local control should be re-established. This leads to a transformation of the field, whereby the social structure of the field would be transformed.

The following phases briefly outline the way this conflict has been played out over time in Germany.

\section{Phase one (-1998)}

The origins of the RE movement can be found mainly in the anti-nuclear power movement and, to a lesser extent, in protest movements against large industry / government projects. Scientists who were eager to develop alternatives to nuclear energy were part of the movements, as were many (organised) activists willing to build experimental installations. An important window of opportunity for these groups opened with the rising electoral successes of the Green Party in the 1980s and 1990s, which was eager to pick up the energy question. In some communities with a strong Green support, local energy solutions were experimented with, operating with different organisational and technological mixes. The attitude of the incumbent energy providers as well as the government was outspokenly hostile. The energy providers tried by various means to block the feed-in of renewable energies into the grid and the government provided only very limited support. With the help of working experiments, during the 1990s RE actors managed to organise themselves into various associations, gained high public support, and NGOs such as Greenpeace and others lobbied intensively for RE. In a way it can be said that local niches were formed in this period but which, however, had little support or protection from the federal government.

\section{Phase two (1998-2008)}

These efforts became more meaningful when a new window of opportunity opened in 1998 with the formation of a red-green coalition government on the federal level. Green politicians with experience in local energy experiments entered the Parliament and the 
group around the Social Democratic Party of Germany member and solar activist Herman Scheer was successful in engineering a new regulatory framework for RE. This helped to kick-start a dynamic RE development and the formation of an ever broadening RE support coalition. Based on a high approval rate in the overall population, a quickly expanding RE industry formed, the local and state government became interested in RE not only because of its green credentials but also because of the economic benefits (new jobs, new taxes) that came to be associated with RE. Experiments became more widespread in these years and owing to the changes in the regulatory framework, the economics of the experiments became more calculable.

\section{Phase three (2008-2012)}

Things took a turn for the worse in phase three which started with the formation of the conservative-liberal coalition in 2008. The main developments were not directly linked to the formation of the new government but the way arising problems were addressed changed significantly. At the onset the liberal party demanded that the support structure for RE had to be dismantled. Even if they were not successful with this demand, it set the tone for the ensuing discussions. Instead of promoting RE, the government extended the running times of existing nuclear power plants while the support coalition for RE began to crumble. The German RE industry suffered greatly from cheap, mainly Chinese imports. The bulk of the industry disappeared again and along with it the hopes of local and state politicians for economic rewards.

This all led to regulatory amendments, which generally tried to make the situation for $\mathrm{RE}$ more difficult, especially for the small, decentralised units doing the experiments. Instead of support for small units, private households, farmers etc., larger installations like off-shore wind and solar parks became the new beneficiaries. Experiments were now conducted in an environment that became increasingly hostile to the idea of experiments as transformative practice which in turn resulted in a growing sense of insecurity among the participants.

\section{Phase four (2012 - to present)}

The government's intention to make RE growth more manageable had failed for several years. The government regularly had to upgrade projections, because the growth of installations was much quicker than anticipated. In phase four (starting with the formation of the Grand Coalition in 2012) the system for supporting RE was changed again in order to finally put a stop to the quick expansion of RE and save the incumbents. The new regulatory initiative passed in 2014 explicitly mandated the upper limits for RE expansion for the first time, and was especially targeted at bioenergy and solar energy. But what had started as more or less isolated and unconnected experimentation in the 1980s and 1990s has now become an established part of a new system, which however is still in the phase of formation without a stable social structure. 


\section{WHAT IS A BIOENERGY VILLAGE?}

One of the elements contributing to the localist character of the German electricity transition is the attempt by communities, cities and regions to move to an energy supply that is based $100 \%$ on RE. These attempts after 1998 are taking place within a marketenvironment, meaning that the respective entities cannot force citizens to go along with this intention. In order for it to be successful, citizens will need to organise and be convinced in a variety of ways to support these attempts by actions of their own, e.g. switching to a new electricity provider, or becoming a member of an energy cooperative, etc. Furthermore, the $100 \%$ RE aim can mean very different things. In some instances, this would mean that locally consumed electricity should also be produced locally. In other cases, the overall electricity balance is important. While the urban utilities company of the city of Munich is turning 100\% renewable, it still however operates a coal-fired power plant in the city. In order to balance this, the utilities company has invested in offshore wind parks in Scandinavian countries and solar farms in Spain.

In this section, we will deal only with one type of experiment: the "bioenergy village movement". The research focuses on those villages that between 2007-2016 were listed on the Federal Ministry of Food and Agriculture's website. This means that other villages not interested in receiving official recognition were left out and newer additions were also not considered.

The Ministry (BMEL) gives a set of defining characteristics that allow villages to appear on the list: the energy supply of the village - electricity as well as heat - is to be supplied by at least $50 \%$ of locally produced energy. Citizens in these communities had to have participated in the decision-making process leading to the formulation of the "bioenergy village". The equipment for bioenergy production is to be at least partially owned by local farmers or local consumers. The biomass used has to be sourced from the immediate vicinity of the village. The village has to establish procedures to regularly evaluate what measures for improving energy efficiency and energy saving are working. The use of biomass can be supplemented by the use of other renewable energies such as wind or solar power (BMEL, 2015).

These characteristics show that we are dealing with a small, clearly delineable, and in some way "elite" group of villages receiving a very limited amount of public support for their organisational efforts. The website mentions 172 villages (March 2016) which satisfy the above-mentioned criteria. Of these, 121 have already made significant progress. Figure 1 shows the geographical distribution of these villages. We can clearly see a major concentration of bioenergy villages in the south of Germany. In order to be on BMEL's list, all initiatives have to additionally demonstrate that their activities are economically viable. Nevertheless, the activities in the northern parts of Germany are clearly dominantly driven by motives of economic and community rejuvenation, while activities in the (economically prospering) south are more driven by ecological motivations. In the remainder of the paper, we will concentrate our analysis on the villages in the south-west of Germany (the state of Baden-Württemberg). 


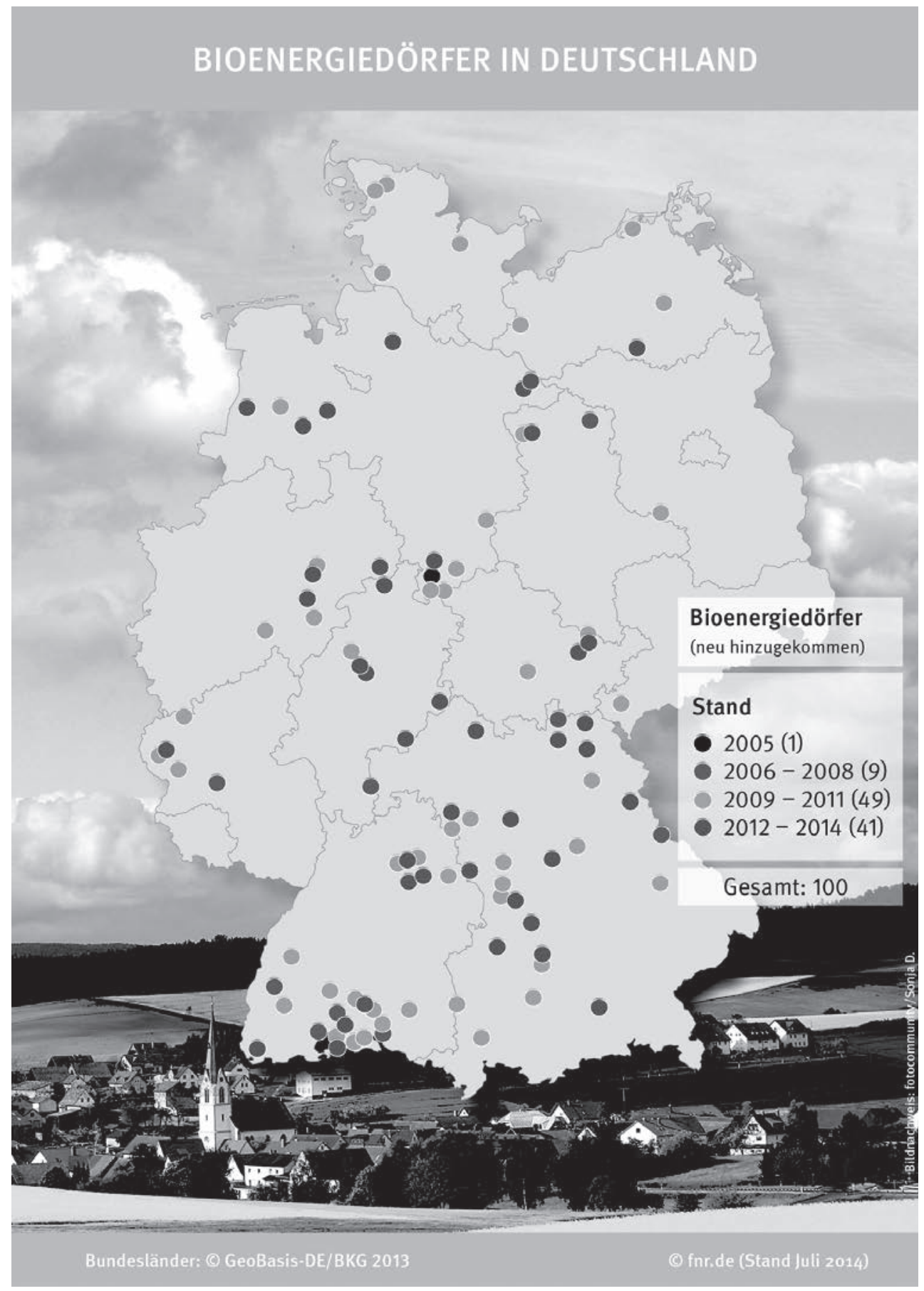

Figure 1. Bioenergy villages in Germany (BMEL, 2016) 
The history of bioenergy villages precedes the BMEL listing. Some of the bioenergy villages have a long-standing history and want to appear on the list because of the (modest) financial support that might come along with it and / or to heighten the visibility of their efforts. In Baden-Württemberg, farmers made their first biomass experiments in the struggle against the plans of the automobile manufacturer Daimler to build a test track in a hilly, agrarian neighbourhood, or in taking a stand against the stationing of cruise missiles or construction of nuclear power plants. A significant motivation for these actors was to do something against "big government" and "big industry" and for them energy seemed to be a good testing ground. The above highlights (1) the importance of civil society actors in the electricity transition in Germany, and (2) hints at the fact that actors becoming active in the transition are motivated by a variety of aims (e.g. against "big business", "big politics") and not necessarily linked to energy alone.

Other initiatives were only started once the institutional framework was set up to accommodate these experiments and could provide blueprints for a successful operation. As outlined above, the intentions of the actors in the movement thus differ depending on the specific context within which the initiatives began. While in the 1990s ecological and political motivations were dominant, over time economic motives for the creation and development of initiatives were becoming more important. This was both the result of a "show effect", with the example of economically successful experiments inciting others to try similar things, as well as the result of the developing political support structures, which demanded economic viability for projects that received public assistance. Some basic data on the initiatives researched: In spring of 2015, there were 28 fully operating bioenergy villages listed in Baden-Württemberg. Given the specific technology used for the transition experiments and the requirements for appearing on the list, it is no wonder that the communities in which the initiatives became active are small in size and almost none of them feature a high degree of industrial activity. They are either situated in an agrarian or suburbanite environment. Politically, they are not significantly different from the average comparable communities in the state, meaning that they have mostly conservative majorities.

Table 1. Organising of bioenergy villages. Types of organisation dominating mobilisation efforts

\begin{tabular}{|l|c|}
\hline Type of organisation & Cases \\
\hline Religious welfare organisation & 1 \\
\hline Local individual companies / persons & 5 \\
\hline Energy cooperatives & 7 \\
\hline Regional association & 1 \\
\hline Solarcomplex AG & 8 \\
\hline Municipal energy provider & 6 \\
\hline Total & 28 \\
\hline
\end{tabular}

Source: Own calculations based on data provided by the bioenergy villages 
Organisationally, however, they differ quite starkly. By organisationally we mean both what kind of organisation was driving the efforts to establish a bioenergy village and what type of organisation was created by the members of the village to achieve the RE aims (see Table 1).

Table 1 shows that organisations propagating RE aims do not have to be located in the village itself. Regional associations, (external) municipal energy providers, etc. can be found next to community-based organisations, making a significant difference in terms of diffusion of learning. External actors are usually engaged in these experiments with the aim of spreading a successful practice. Community-based mobilisation efforts might be satisfied with a successful realisation of the plans within the specific community. We will call the actors who are mainly operating within the confines of a community whose system of electricity generation and distribution is to be transformed endogenous actors. Actors operating not only in the community of interest, but in several others as well are grouped under the heading "external actor involvement". For formal reasons, each initiative needs to state an initiating responsible organisation when it tries to achieve formal recognition as being on its way to becoming a bioenergy village. This information was used for our classification and additionally supported by document research and interviews.

Another important distinction seems to be that for-profit as well as non-profit organisations (such as welfare organisations) are to be found among the mobilising actors. Considering these two distinctions will allow us to develop the following matrix (see Table 2).

Table 2. Cases and actor constellations

\begin{tabular}{|l|l|l|}
\hline & Profit orientation & Public interest \\
\hline $\begin{array}{l}\text { External actor involve- } \\
\text { ment }\end{array}$ & $\begin{array}{l}\text { I. Social entrepreneur } \\
\text { (e.g. Solarcomplex AG) }\end{array}$ & $\begin{array}{l}\text { II. Local / regional authorities } \\
\text { (e.g. administrative units, public } \\
\text { organisations) }\end{array}$ \\
\hline Endogenous actors & $\begin{array}{l}\text { III. Local companies } \\
\text { (e.g. farmers) }\end{array}$ & $\begin{array}{l}\text { IV. Associations (e.g. welfare or } \\
\text { nature conservation groups) }\end{array}$ \\
\hline
\end{tabular}

For the purposes of our study we can thus differentiate between four constellations which differ with respect to dominant motives and framing efforts (either profit orientation or public interest) as well as the type of actors involved in advancing the initiative (either external or endogenous actors). They thus represent different patterns of organising and framing. We highlight the role of external actors in the mobilisation efforts, since their role has been a matter of dispute in movement research. Can a community be effectively mobilised by non-community based actors? Mobilisation of citizens in all cases - as mentioned above - is important because in living in a situation of liberalised markets no individual can be forced to switch to a different energy supplier or experiment with new forms of supply and distribution. Citizens have to be persuaded to par- 
ticipate in order to make the initiatives an eventual economic and / or political success. The cases are thus aligned along these two dimensions (see Table 2) with the first one being: who was the driving actor in the development of the local initiative? We distinguish between an endogenous development in which the original initiative mainly comes from within the community, and an exogenous development in which the development was driven by actors from outside the community. At this point, we are only interested in the question of who is present in the origins of the initiatives. Once the experiments become operative, different types of dedicated organisations need to be established for running the experiment. We will not deal with the specifics of these organisations in this paper. The mechanisms of genesis are different from the mechanisms that allow for a smooth operation of the experiments. The question of origins is underdeveloped in the existing research, which very often treats experiments as a given, but underestimates the challenge that without people interested in doing the experiments they would not exist. Let us illustrate this distinction with some examples. We will distinguish between four types of actor constellations as presented in Table 2, which correspond to the four quadrants in the same table.

Type 1: In these cases, the goal of the energy transition is driven forward by Solarcomplex AG. As Table 1 shows, the company has been instrumental in eight of the 28 analysed cases. Solarcomplex AG in particular invests in solar energy and bioenergy villages. It acts as a driving force and can be seen as a pioneer for developing business cases in the field of renewable energies. In our sample, Solarcomplex AG is unique both with respect to the number of times it appears as a driving force as well as a type of external economic actor. Solarcomplex AG is an example of a private actor who actively addresses local communities and tries to convince them that to go renewable is a socially desirable as well as an economically feasible goal. Solarcomplex AG was initially founded by social movement actors without any profit motives, but who were convinced about the social desirability of their aims. In spite of the fact that the company has meanwhile put the economic viability of its projects centre stage, it accepts and takes on substantial economic risks in the process of persuading local communities. In sum Solarcomplex AG is not an endogenous actor and in principle follows the imperatives of economic viability, which, however, are not in competition with the goal of working for the spread of RE.

Type 2: The regional management of the development concept for achieving a 100\% $\mathrm{RE}$ supply is coordinated by a regional agency. It is run and supported by a host of actors from within and outside the region (e.g. various ministries, the European Commission, regional banks). In these cases, public waste disposal companies, $100 \%$ owned by regional or local public bodies, are important or otherwise part of the public administration which was told to participate in politically important projects.

Type 3: The cases in this field are organised by local companies or single individuals. In our cases these are mostly farmers who own already existing biomass installations and want to expand them or who intend to build new ones. Companies or individuals engaged in forestry management are another group. 
Type 4: Mobilisation efforts in this group are managed by local or regional citizen groups. These can be religiously motivated groups as well as nature conservation groups. Their aims are oriented nearly exclusively towards the improvement of the local situation and they also operate mainly with local resources. The experiments need to be economically viable, but to prove the economic success of the experiments is not a motivating factor.

The preparation to get a bioenergy village experiment under way usually takes a few years. During these years, it has to be established that actors are available to run the entire operation, that viable ideas about the technologies to be used exist, that ideas about potential financing are realistic. This is followed by attempts to persuade citizens to participate in the experiment, to sign contracts, to enter into obligations, etc. Once a critical mass of citizens is prepared to go along with the project, the essential technical elements can be built, usually with the help of credits next to seed money sourced from the citizens in the community. Favourable loans were available from public banks. In order to run the experiment a dedicated organisation has to be created. Once the experiment starts and electricity is fed into the grid, the running time of the installations was considered to be at least 20 years. This is due to the feed-in tariff regulations that were in operation until 2014. Once in operation in order to be able to call oneself a bioenergy village, the majority of electricity and heat that is consumed and generated in the community has to be provided by the seed organisation.

The temporal aspect in the development of these initiatives looms large overall but we are not investigating this at this point. We just refer to the general history addressed in section 2 for background information and mention that the decision to go for a bioenergy village experiment can be one step in a longer sequence of experiments. Pioneer local communities have usually been driven forward by endogenous actors with strong ecological credentials and each experiment possesses a strong local flavour.

Let us now look at one of the 28 initiatives in more detail. This example has been chosen because it illustrates a longer time development within which the biomass experiment was embedded.

\section{CASE NO. 17}

The origins of energy related activities in this small community in the southwest of Germany are linked to a citizen initiative, which was formed in the late eighties after plans had been announced for the construction of a large composting plant. The citizen initiative opposing the construction of this plant eventually turned into a local party and in 1989 was able to win four out of eleven seats in the village council. Since alternatives to the composting plant had to be sought, the citizen initiative collected information on biogas and biomass. In 1990 the citizen initiative turned local party was able to win the position of mayor. The central issue in the electoral campaign had been the composting plant. The mayor was building up contacts with a renowned expert in the field of bioenergy who by coincidence lived in the same neighbourhood. These two closely 
cooperated in developing the first concepts for an installation. Out of this cooperation a core group came into existence consisting of "respected" persons from the community and in spite of the fact that the political incumbents had lost the election over this issue, and which understandably led to a certain uneasiness (up to 2012 the conservative party in the state of Baden-Württemberg was unchallenged in its leading political role), the community offered its broad support. The core group consisted of the mayor, the mentioned biogas expert, the manager of a local company engaged in Photovoltaics (PV), and a representative of a local bank.

Once the plans had been approved, financial support from the EU and the state government was secured. At this point resistance in the community became organised and the creation of a new citizen initiative this time against the biomass installation was debated. The mayor and his core group could withstand the opposition especially by promoting openness, holding regular meetings with the population, bringing in people from the outside who stressed the lighthouse character of the plans. Later on farmers again voiced their protest against the installation. All this opposition activity, however, lacked a steady organisation and people grouped around single issues for only a short period. The opponents moreover did not link up to state wide or national organisations opposed to bio or RE plans.

For the running of the installation, a dedicated organisation was eventually founded which consisted of 60 partners (farmers, equipment producers, interested citizens etc.). Due to problems related to the complexity of the installation, the project, however, soon became merged with other "green" projects in the area, which then were all managed by a common board. The biomass installation in this case was the first of its kind in Germany with an official permit to ferment the remaining food. In spite of the fact that many observers call this installation the mother of all other similar installations in Germany, it was shut down in 2009. At the time the installation provided electricity for $20 \%$ of all homes in the community. The community, however, was not willing to pay for the modernisation of the installation, since new opposition had been formed. This opposition was mainly spurred by the growth of the installation and ensuing problems such as lorry traffic, etc. In addition, three meeting halls had been built to accommodate public interest in this model community and for holding meetings of biogas specialists, biogas associations, exhibitions, etc.

Nevertheless, at this time the community was no longer only experimenting with biomass. PV installations had spread in the community with the support of the aforementioned local company. In 2011, the community became the leading solar community in the state of Baden-Württemberg. In spite of the fact that larger PV installations were successfully opposed by local farmers, two windmills set up by groups of citizens were approved. But the increasing production of energy proved difficult to manage. Up to 2011 a local network operator was responsible for the traffic and the continuous provision of energy locally and the export of surplus energy. Given the increasingly complex nature of the task and growing regulatory requirements for decentralised installations, the operator was forced to sell out to the regional oligopolist EnBW (one of the four lar- 
gest utility companies in Germany). Whether this will have an influence on the further development of energy related initiatives in this community remains to be seen. In spite of the constant struggles and resistance against individual projects, a representative survey among the inhabitants of the community revealed that $88 \%$ of the population supported the overall line of development within the community, and $87 \%$ claimed to be in favour of further development of renewable energies.

This case is a prime example of a community jumping early on the idea of renewable energies. The idea was driven forward by skilled individuals which through determinate coalition building with various factions of the population achieved a broad support within an environment that did not seem to be conducive to experiments: conservative and rural. The example also shows that the choice of technologies was more or less opportunistic. The technology development and implementation as such was not a determining factor, but rather the availability of different types of technologies supported by local expertise. Unlike in other communities, opposition against individual projects such as solar farms or the modernisation of the biomass installation did not reroute the community from its path towards becoming $100 \%$ renewable. Opposition, as in many other cases, came from farmers, who feared increasing property prices that would damage their core business, and from the population when it gained the impression that things had become too immense and thus were damaging the promise of the project initiators to remain small and close to home.

\section{DISCUSSION}

In the beginning we defined the experiments with respect to the possibility of developing solutions that violated a dominant field logic. A diffusion of experiments in this sense would mean that the preparedness of people to engage in such activities increases and that the institutional environment becomes conducive to such activities. This also implies that experiments can be found most prominently in times when fields are being newly created or established fields come under pressure. This furthermore implies that experiments in this sense will rather be the exception than the rule.

The bioenergy village experiments as discussed here fit these expectations. The example of bioenergy villages shows how a broader movement based on single, isolated pockets of experimentation can develop and which allowed bioenergy villages to become an established part of a new electricity system. It is quite clear that the whole of Germany cannot be transformed into a bioenergy village. The bioenergy village movement nevertheless is important because it helps us understand why the German transition movement had and still has such a strong localist flavour. Experiments of very different kinds, using different technologies and working with very different organisational solutions, can be found. Given the changes in the overall political framework, the localist character might lose some of its importance in the future, but will remain at the centre of the electricity transition for years to come. The bioenergy village movement also shows that the diffusion of the experiments was initially driven by actors trying to 
make hands-on experiments with unproven technology and organisational structures (phase one). Once these initiatives had received official recognition (end of phase two), diffusion also became a task of dedicated political and bureaucratic entities. This, on the one hand, might have helped accelerate the diffusion process, but on the other hand, given the set of requirements to be officially recognised as a "bioenergy village", also limited the range of experimentation along a recognised trajectory. Nevertheless, this still left enough space for a differentiated implementation given the strong emphasis of relying on local actors and structures. In each village institutional entrepreneurs had to be available for mobilising citizens and building coalitions for the realisation of the experiment. Entrepreneurs are still required for the process, as the established structures of the local field of electricity generation and distribution have to be destroyed before a new structure can be established. Existing contracts and obligations have to be cancelled and the relationships with the former incumbent actors given up or re-oriented. Given the changing regulatory framework, this became easier in the diffusion period but has become more difficult again in the present circumstances. Meanwhile, much more specialised expertise is required for attempts to reorganise local electricity systems, which makes citizens dependent on professional external support.

The analysis of the bioenergy village cases has also clarified that at least in the case of community electricity transformation, experiments cannot be interpreted as isolated, clearly delineable events. Formally, experiments within the regulatory framework for the promotion of renewable energies are aiming at a life time of at least 20 years. For this period of time feed-in into the grid is guaranteed. The discussion of Case no. 17, however, has shown that we have to distinguish between the formal rules and the actual emergent developments. Following the establishment of the experiment, safeguarding the experiment will be the dominant motive along with adapting it to changing requirements and environments, which might lead to significant changes to the original design. The climate governance experiments did not fit into an existing climate governance configuration. If we define governance as the mode how actors go about dealing with specific problems, the governance configuration has changed. New actors (citizen groups, associations etc.) have become relevant actors in the governance configuration and the ways to pursue aims, while the aims themselves and the way conflicts are being resolved has changed as well.

None of the individual experiments has led directly to major climate policy changes, but successful experiments did work as a reference point for the restructuring of the regulatory framework after 1998. The old incumbents are no longer able to simply try to prevent the experiments from spreading and becoming successful, but meanwhile they are positioning themselves as partners and system integrators for local reorganisation. This is also part of a greater reconfiguration in the positioning of the old incumbents. In many cases, the dominating utility companies did not have direct access to local distribution networks and the end customer in the past. Given the new governance frame, utility companies are no longer concentrating their business model on the sale of a standardised electricity product to a more or less anonymous client. 


\section{CONCLUSION}

The paper started with the assumption that civil society actors, local and regional communities are at the forefront of efforts to change the electricity supply system in Germany (Morlet and Keirstead, 2013:852). An overview of the relevant activities provided evidence for this assessment. We further assumed that specific spatial context factors are important for understanding the development and eventual shape of these decentralised initiatives. In analysing the cases of bioenergy villages, it was shown that they in fact vary considerably according to the context out of which the initiatives were growing. We claimed that the initiatives are being advanced by a heterogeneous group of actors with varying aims, which take under consideration local power constellations, spatial conditions, and the existing set of technological options insofar as spatial elements (of a social as well as ecological nature), political conditions, economic structures, settlement profiles, available material resources (wind, sun, wood, biomass) matter. A categorisation of the 28 cases of bioenergy villages in Baden-Wuerttemberg and an indepth case study of one bioenergy village substantiated this point.

\section{REFERENCES}

BMEL (Federal Ministry for Food and Agriculture) (2016). Bioenergiedörfer. URL: http://www.wege-zum-bioenergiedorf.de/bioenergiedoerfer/ (March 24, 2016).

Bourdieu, P. and Wacquant, L. (1992). Invitation to a Reflexive Sociology. Chicago: University of Chicago Press.

Bundesregierung (2016). Energiewende. Maßnahmen im Überblick. https://www. bundesregierung.de/Content/DE/StatischeSeiten/Breg/Energiekonzept/0-Buehne/ ma\%C3\%9Fnahmen-im-ueberblick.html (March 24, 2016).

Fettke, U. and Fuchs, G. (2016). Incumbent-Challenger Interaktionen und die Veränderungen im Markt für Stromerzeugung und -verteilung in Deutschland. In: Giacovelli, S. (ed.), Die Energiewende aus wirtschaftssoziologischer Perspektive. Theoretische Konzepte und empirische Zugänge (pp. 15-44). Wiesbaden: Springer VS.

Fligstein, N. and McAdam, D. (2011). Toward a General Theory of Strategic Action Fields. Sociological Theory, 29(1): 1-26.

Fligstein, N. and McAdam, D. (2012). A Theory of Fields. Oxford: Oxford University Press. Geels, F. W., Kern, F., Fuchs, G., Hinderer, N., Kungl, G., Mylan, J., Neukirch, M., Wassermann, S. (2016). The enactment of socio-technical transition pathways: A reformulated typology and a comparative multi-level analysis of the German and UK low-carbon electricity transitions (1990-2014). Research Policy, 45(4): 896-913.

Hodson, M. and Marvin, S. (2010). Can cities shape socio-technical transitions and how would we know if they were? Research Policy, 39(4): 477-485.

Martin, J. L. (2003). What is Field Theory? American Journal of Sociology, 109(1): 1-49 Martin, J. L. (2011). The Explanation of Social Action. New York: Oxford University Press. 
Mieg, H. A. And Töpfer, K. (eds.). (2013). Institutional and Social Innovation for Sustainable Urban Development. Oxon: Routledge.

Morlet, C. and Keirstead, J. (2013). A comparative analysis of urban energy governance in four European cities. Energy Policy, 61: 852-863.

Padgett, J. F. and Powell, W. W. (eds.). 2012. The Emergence of Organizations and Markets. Princeton: Princeton University Press.

Priemus, H. and Davoudi, S. (eds.) (2014). Climate Change and Sustainable Cities. London: Routledge.

Scharpf, F. W. (1997). Games real actors play: actor-centered institutionalism in policy research. Boulder, CO: Westview Press. 


\title{
POKRET BIOENERGETSKOG SELA U NJEMAČKOJ: KORAK NATRAG ILI REORGANIZACIJA ENERGETSKOG SUSTAVA BUDUĆNOSTI?
}

\author{
Gerhard Fuchs
}

\begin{abstract}
Sažetak
Njemačka je trenutno u procesu transformacije svog sustava proizvodnje i distribucije električne struje. Tom su procesu doprinijeli mnogi akteri civilnog drustva, koji su željeli dokinuti stari, centralizirani, nedemokratski, ekološki neprikladan i nezdrav sustav i zamijeniti ga novim, koji bi bio bliži ljudima, decentraliziran i koji bi koristio obnovljive izvore energije. Jedan od načina je pokret bioenergetskog sela, kojeg najčešće pronalazimo u većinski poljoprivrednim područjima, koja se uglavnom oslanjaju na biomasu kao prijelaznu tehnologiju. Do sada nema provedene sustavne analize djelovanja ovog pokreta. U ovom radu smještamo njegovo djelovanje u kontekst transformacije koja se odvija na području električne energije u Njemačkoj i analiziramo aktere uključene u pokret, njihove motivacije i strategije koje koriste u svom djelovanju. Pokazat ćemo da usprkos tome što se ne radi o brojčano velikom pokretu, on predstavlja važan korak ka razvijanju nove infrastrukture električne energije. Razmatramo i je li odabrani teorijski okvir (teorija polja strateškog djelovanja) koji koristimo za analizu ovog pokreta prikladan i za analizu sličnih procesa transformacije.

Istraživanje je provedeno u okviru njemačkog Helmholtz udruženja pod nazivom „S onu stranu energije: oblikovanje infrastruktura za energetske potrebe budućnosti. Prema održivosti i socijalnoj kompatibilnosti“.
\end{abstract}

Ključne riječi: biomasa, električna energija, Njemačka, bioenergetska sela, socijalni poduzetnici

\section{BIODORFBEWEGUNG IN DEUTSCHLAND: EIN SCHRITT ZURÜCK ODER REORGANISATION DES ENERGIESYSTEMS DER ZUKUNFT?}

\author{
Gerhard Fuchs
}

\section{Zusammenfassung}

Deutschland befindet sich momentan in einem Prozess der Transformation von Produktion und Distribution elektrischen Stroms. Diesem Prozess haben viele Akteure der Zivilgesellschaft beigetragen, die dem alten, zentralisierten, undemokratischen, ökologisch inadäquaten und ungesunden System ein Ende machen, und es durch ein neues dezentralisiertes ersetzen wollten, das den Menschen näher wäre und das erneuerbare Energiequellen nutzen würde. Eine Art der Aktivitäten ist die Biodorfbewegung, die meistens in vorwiegend landwirtschaftlich orientierten Gebieten stattfindet, die sich hauptsächlich auf Biomasse als Übergangstechnologie stützen. Bisher hat es keine systematisch durchgeführte Analysen der Wirkung dieser Bewegung gegeben. In dieser Arbeit wird ihre Wirkung in den Kontext der Transformation im Bereich der elektrischen Energie in Deutschland eingebettet und wir analysieren die an der Bewegung mitwirkenden Akteure, deren Motive und Strategien, die sie in ihren Aktivitäten benutzen. Wir werden zeigen, dass es sich, trotz der zahlenmäßig nicht gerade großen Bewegung, um einen wichtigen Schritt zur Entwicklung einer neuen Infrastruktur für elektrische Energie handelt. Wir ziehen auch in Betracht, ob sich der gewählte theoretische Rahmen (Theorie der strategischen Handlungsfelder), den wir zur Analyse dieser Bewegung nutzen, auch zur Analyse ähnlicher Transformationsprozesse eignet.

Die Forschung wurde im Rahmen der deutschen Helmholtz-Gemeinschaft durchgeführt unter dem Titel "Jenseits der Energie: Bildung von Infrastrukturen für den Energiebedarf der Zukunft. In Richtung Nachhaltigkeit und sozialer Kompatibilität".

Schlüsselwörter: Biomasse, elektrische Energie, Deutschland, Bioenergiedörfer, Sozialunternehmer 